\title{
GAMBARAN PENGETAHUAN KELUARGA TENTANG EFEK SAMPING KEMOTERAPI PADA ANAK DI YAYASAN KASIH ANAK KANKER YOGYAKARTA
}

\author{
Fatma Laili Nugraheni, Ida Mardalena, Yustiana Olfah \\ Jurusan Keperawatan Poltekkes Kemenkes Yogyakarta \\ Jalan Tata Bumi No.3 Banyuraden, Gamping, Sleman, Yogyakarta, 55293 \\ fatmalaili11a3@gmail.com \\ ida.mardalena@yahoo.co.id \\ yustianajogja@gmail.com
}

\begin{abstract}
Cancer is one of the leading causes of death worldwide. Basic Health Research The Results of Basic Health Research 2013 (Riskesdas) shows the prevalence of cancer of children aged 0-14 years amountdeto 16,291 cases. While the most common type of cancer suffered by children in Indonesia is leukemia and eyeball cancer or retinoblastoma. Chemotherapy is a cancer treatment using drugs or hormones. Children who undergo chemotherapy will experience symptoms as nausea, vomiting, decreased appetite, fever and fatigue (fatigue). The purpose of this study is to determine the description of family understanding about the side effects of chemotherapy in children in Yayasan Kasih Anak Kanker Indonesia-Jogjakarta. This research uses descriptive research type with research design that is quantitative. The sampling technique used is total sampling with 45 respondents. The instrument used is questionnaire. This research was conducted from March 2017 until May 2017. It was found that some respondents had good knowledge about chemotherapy side effect that is 25 people $(59,5 \%)$. Characteristics of respondents who had good knowledge are respondents whose age in the range of 36-45 years (28.6\%). Respondents who had good knowledge about the side effects of chemotherapy were respondents who had a junior secondary education of 12 respondents $(28.6 \%)$, with IRT work of 13 (30.9\%), earning less than Rp.1.500.000 and respondents Never get information has good knowledge. The researchers concluded that some respondents had good knowledge about the side effects of chemotherapy.
\end{abstract}

Keywords : Family, Effects Of Chemotherapy

\begin{abstract}
Abstrak
Penyakit kanker merupakan salah satu penyebab kematian utama di seluruh dunia.Hasil Riset Kesehatan Dasar tahun 2013 (Riskesdas) menunjukkan prevalensi kanker anak umur 0-14 tahun sebesar sekitar 16.291 kasus.Sementara jenis kanker yang paling banyak diderita anak di Indonesia yaitu leukemia dan kanker bola mata atau retinoblastoma.Kemoterapi merupakan pengobatan kanker dengan menggunakan obat-obatan atau hormon. Anak yang menjalani kemoterapi akan mengalami seperti mual, muntah, penurunan nafsu makan, demam dan keletihan (fatigue). Tujuan dilakukan penelitian ini adalah diketahuinya gambaran pengetahuan keluarga tentang efek samping kemoterapi pada anak di Yayasan Kasih Anak Kanker IndonesiaJogjakarta.Penelitian ini menggunakan jenis penelitian deskriptif dengan desain penelitian yaitu kuantitatif.Teknik sampling yang digunakan adalah total sampling dengan jumlah 45 responden.Instrumen yang digunakan yaitu kuesioner.Penelitian ini dilakukan dari bulan Maret 2017 sampai dengan Mei 2017. Didapatkan hasil bahwa sebagian responden memiliki pengetahuan baik tentang efek samping kemoterapi yaitu sebanyak 25 orang $(59,5 \%)$. Karakteristik responden yang memiliki pengetahuan baik adalah responden yang usianya dalam rentang 36-45 tahun $(28,6 \%)$. Responden yang memiliki pengetahuan baik tentang efek samping kemoterapi adalah responden yang memiliki pendidikan terakhir SMP sebanyak 12 responden
\end{abstract}


$(28,6 \%)$, dengan pekerjaan IRT sebanyak 13 (30,9\%), memiliki penghasilan kurang dari Rp.1.500.000 dan responden yang pernah mendapatkan informasi memiliki pengetahuan yang baik. Kesimpulan peneliti bahwa sebagian responden memiliki pengetahuan baik tentang efek samping kemoterapi.

\section{Kata Kunci : Keluarga, Efek Samping Kemoterapi}

\section{Pendahuluan}

Terminologi "Kanker Anak" biasanya digunakan pada diagnosis kanker yang terjadi pada anak sampai usia 18 tahun. Menurut data Union for International Cancer Control (UICC), setiap tahun terdapat sekitar 176.000 anak yang di diagnosis kanker, yang mayoritas berasal dari negara berpenghasilan rendah dan menengah. Meskipun kejadian kanker pada anak di seluruh dunia masih cukup jarang, namun kanker merupakan salah satu penyebab utama kematian 90.000 anak setiap tahunnya (Kemenkes, 2015).

Hasil Riset Kesehatan Dasar tahun 2013 (Riskesdas) menunjukkan prevalensi kanker anak umur 0-14 tahun sebesar sekitar 16.291 kasus.Sementara jenis kanker yang paling banyak diderita anak di Indonesia yaitu leukemia dan kanker bola mata atau retinoblastoma (Depkes, 2016).Kasus di RSK Dharmais sejak tahun 2006 sampai 2014 mengalami peningkatan. Peningkatan tertinggi pada tahun 2011 yaitu 63 kasus pada tahun 2010 menjadi 122 kasus pada tahun 2011. Pada tahun 2014 kasus tertinggi pada leukimia yaitu sebanyak 46 kasus. Lymphoma sebanyak 19 kasus, Rhabdomyosarcoma 13 kasus, brain tumor 13 kasus, osteosarcoma 9 kasus dan retinoblastoma sebanyak 7 kasus (Kemenkes, 2015).

Menurut Yayasan Kasih Anak Kanker Indonesia dan riset di RSUP Dr Sardjito Yogyakarta leukimia atau kanker darah adalah kanker yang paling banyak ditemui pada anakanak.Menurut data RSUP Dr Sardjito Yogyakarta, menunjukkan bahwa jumlah pasien leukimia anak adalah 54\%.Retinoblastoma atau kanker mata merupakan kanker kedua yang paling banyak menyerang anak.Jumlah kasus di Yogyakarta adalah 121 kasus atau sekitar 7\%.Neuroblastoma yang merupakan sejenis kanker saraf yang memiliki banyak gejala.Jumlah kasus neuroblastoma hampir sebanyak kasus retinoblastoma yakni 5\% kasus (Husnantiya, 2014).

Kemoterapi merupakan pengobatan kanker dengan menggunakan obat-obatan atau hormon.Kemoterapi dapat digunakan efektif pada penyakit-penyakit baik yang masih terlokalisasi (Saleh, 2010).Efek samping dari kemoterapi yaitu gejala gastrointestinal, supresi sumsum tulang, dan kerontokan rambut.Gejala gastrointestinal seperti mual, muntah, diare dan mukositis.Sedangkan gejala klinis supresi sumsum tulang disebabkan oleh terjadinya penurunan jumlah sel darah putih, leukosit, dan sel darah merah (Reksodiputro, 2014). Berdasarkan hasil penelitian Nurhidayah, dkk (2013) didapatkan bahwa anak yang menjalani kemoterapi $76,2 \%$ responden memiliki riwayat pengalaman mukositis pada kemoterapi sebelumnya, $80,9 \%$ responden mendapatkan jenis kemoterapi dengan tingkat mukosa toksik tinggi. Selain itu, efek samping yang ditimbulkan pada pasien leukimia akibat kemoterapi adalah mengalami penurunan berat badan, bibir sariawan, wajah pucat, dan kerontokan rambut (Lestari, 2013).Penelitian Lestari (2013) ini, menunjukkan bahwa semakin lama kemoterapi, maka body image responden (anak) semakin buruk.

Pengetahuan merupakan salah satu faktor internal dalam motivasi, sehingga bila pasien mempunyai pengetahuan yang baik tentang kemoterapi, diharapkan akan mempunyai motivasi yang tinggi dalam menjalani kemoterapi, karena pasien dapat memahami tujuan kemoterapi dan akan mempersiapkan dirinya untuk mengantisipasi kemungkinan efek samping yang akan timbul, sehingga kemoterapi yang dijalaninya berjalan dengan lancar dan drop out kemoterapi dapat dihindari. Penelitian Musarofah (2009), didapati hasil bahwa, 
semakin tinggi tingkat pengetahuan maka semakin tinggi juga motivasi untuk menjalani kemoterapi.

Yayasan Kasih Anak Kanker Indonesia-Jogjakarta yang sering disebut rumah kita adalah rumah singgah yang disiapkan untuk mengakomodasi pasien anak penderita kanker.Menurut studi pendahuluan yang dilakukan bahwa pasien yang berada di rumah kita selama tiga tahun kurang lebih 150 pasien.Pasien terbanyak yaitu anak dengan leukimia dan paling banyak berumur 5-10 tahun.Menurut salah satu pengurus di yayasan bahwa setiap anak yang datang sering bersama orang tua untuk melakukan kemoterapi di RSUP Dr.Sardjito.Menurut data dari 4 orang tua, 3 orang tua mengatakan efek yang timbul kemoterapi yaitu mual, muntah, sariawan dan rambut rontok.Sedangkan 1 orang tua mengatakan bahwa efek yang timbul yaitu kulit menjadi gosong.Dalam menangani efek samping ini 1 orang tua mengatakan jika anak diminta untuk istirahat dan minum jus.Sedangkan 2 orang tuamengatakan jika anak mual diberikan minum teh.Sedangkan untuk menangani demam menurut pengurus yayasan, anak langsung dibawa ke rumah sakit.Salah satu orang tua mengatakan bahwa belum terlalu paham dalam menangani efek samping dari kemoterapi.Tujuan penelitian mengetahui gambaran pengetahuan keluarga tentang efek samping kemoterapi pada anak di Yayasan Kasih Anak Kanker Indonesia-Jogjakarta.

\section{Metode}

Desain penelitian yang digunakan penelitian survey.Penelitian ini melakukan deskripsi terhadap gambaran tingkat pengetahuan keluarga tentang efek samping kemoterapi pada anak di Yayasan Kasih Anak Kanker Indonesia-Jogjakarta.Populasi dalam penelitian ini adalah keluarga yang memiliki anak yang menderita kanker dan sedang menjalani kemoterapi.Populasi pasien yang menjadi anggota di Yayasan Kasih Anak Kanker IndonesiaJogjakarta tahun 2016 sebanyak 45 pasien.Pengambilan sampel secara total sampling.dilaksanakan pada bulan Maret sampai Mei 2017. Analisis uivriat atau deskriptif yaitu menganalisa tiap variabel peneltian untuk menghasilkan distribusi frekuensi dan prosentase dari tiap variable.

\section{Hasil Penelitian}

Penelitian tentang gambaran pengetahuan keluarga tentang efek samping kemoterapi pada anak di Yayasan kasih Anak Kanker Indonesia-di gambarkan sebagai berikut :

Tabel 1 Distribusi Karakteristik responden

\begin{tabular}{clcc}
\hline No & \multicolumn{1}{c}{ Karakteristik } & frekuensi & persentase \\
\hline 1 & Umur & & \\
& a. $17-25$ tahun & 5 & 11,9 \\
& b. 26-35 tahun & 15 & 35,71 \\
& c. 36-45 tahun & 18 & 42,86 \\
& d. 46-55 tahun & 4 & 9,53 \\
\hline 2 & Pendidikan & & \\
& a. SD & 10 & 23,80 \\
& b. SMP & 20 & 47,70 \\
& c. SMA & 12 & 28,50 \\
\hline
\end{tabular}




\begin{tabular}{llcc}
\hline 3 & Pekerjaan & & \\
& a. Buruh & 7 & 16,67 \\
& b. IRT & 22 & 52,38 \\
& c. Petani & 4 & 9,53 \\
& d. Swasta & 5 & 11,9 \\
& e. Lainnya & 4 & 9,53 \\
\hline 4 & Mendapatkan & & \\
& Indormasi & & \\
& a. Ya & 37 & 88,1 \\
b. Tidak & 5 & 11,9 \\
\hline
\end{tabular}

Data hasil penelitian menunjukkan pada tabel 1.menunjukkan bahwa persentase terbesar kelompok responden yang memiliki pengetahuan dengan kriteria baik yaitu pada responden yang berusia 36-45 tahun (28,6\%). Pendidikan terakhir SMP sebanyak $12(28,6 \%)$, pekerjaan responden IRT sebanyak 13 (30,9\%), penghasilan kurang dari Rp 1.500 .000 sebanyak 13 $(30,9 \%)$ dan responden yang pernah mendapatkan informasi memiliki pengetahuandengan kriteria baik sebanyak $24(57,1 \%)$.

Tabel 2 Distribusi Frekuensi Pengetahuan Keluarga pada Tingkat Tahu tentang Efek Samping kemoterapi Pada Anak di Yayasan Kasih Anak Kanker Indonesia

\begin{tabular}{cccc}
\hline No & Kategori & frekuensi & persentase \\
\hline 1. & Baik & 25 & 59,5 \\
2. & Cukup & 13 & 31 \\
3 & Kurang & 4 & 9,5 \\
\hline
\end{tabular}

Data pada tabel 2 menunjukkan pengetahuan keluarga tentang efek samping kemoterapi pada anak pada tingkat tahu sebagian besar adalah baik yaitu sebanyak 25 responden (59,5\%), cukup yaitu 13 responden (31\%) dan kurang yaitu 4 responden $(9,5 \%)$.

\section{Pembahasan}

Pengetahuan keluarga tentang kemoterapi Dilihat dari persentase tingkat pengetahuan keluarga tentang efek samping kemoterapi pada anak secara umum adalah baik.Pengetahuan yang dimaksud dalam penelitian ini adalah pada tingkat tahu. Menurut Notoatmodjo dalam Wawan dan Dewi (2010) pengetahuan yang dicakup dalam domain kognitif mempunyai 6 tingkatan yang salah satunya pada tingkat tahu (know). Tingkat ini adalah mengingat kembali (recall) terhadap sesuatu yang spesifik dan seluruh bahan yang dipelajari atau diterima.Tingkat tahu merupakan tingkat pengetahuan yang paling rendah.

Berdasarkan tabel 2 menunjukkan bahwa pengetahuan keluarga tentang efek samping kemoterapi secara umum dalam kategori baik yaitu sebanyak 25 (59,5\%). Penelitian ini membahas beberapa aspek yang terdiri dari definisi kemoterapi, tujuan kemoterapi, efek samping kemoterapi jangka pendek, efek samping kemoterapi jangka panjang, penatalaksanaan efek samping kemoterapi jangka pendek, dan penatalaksanaan efek samping kemoterapi jangka panjang. Tingkat pengetahuan keluarga tentang definisi kemoterapi diperoleh hasil dalam kategori baik Dibandingkan dengan aspek yang lain, tingkat pengetahuan tentang definisi menduduki dalam tingkatan pertama daritingkat pengetahuan tentang tujuan kemoterapi, efek samping kemoterapi jangka pendek, efek samping kemoterapi jangka panjang, penatalaksanaan efek samping kemoterapi jangka pendek dan penatalaksanaan efek samping kemoterapi jangka panjang. Masih ada responden yang menyatakan bahwa kemoterapi merupakan pengobatan dengan penyinaran.Sedangkan teori 
menurut Saleh (2010) yang menyatakan bahwa kemoterapi merupakan pengobatan kanker dengan obat-obatan.

Pengetahuan yang baik tentang definisi kemoterapi hal ini didukung karena responden sebagian besar sudah mendapatkan informasi dari petugas kesehatan maupun media lainnya.Walaupun sebagian besar responden berpendidikan SMP. Menurut Notoatmodjo (2010), informasi memberikan pengaruh kepada seseorang meskipun orang tersebut mempunyai tingkat pendidikan yang rendah tetapi jika ia mendapatkan informasi yang baik dari berbagai media, maka hal ini dapat meningkatkan pengetahuan orang tersebut. Tingkat pengetahuan keluarga tentang tujuan kemoterapi diperoleh hasil dalam kategori baik Berdasarkan hasil analisa pernyataan bahwa responden beranggapan kemoterapi dilakukan untuk menyembuhkan kanker secara total.Sedangkan menurut Saleh (2010)bahwa tujuan kemoterapi salah satunya yaitu menghambat metastase sel kanker.

Tingkat pengetahuan keluarga tentang efek samping kemoterapi jangka pendek diperoleh hasil dalam kategori baik Berdasarkan hasil analisis pada setiap soal kuesioner, sebagian responden beranggapan bahwa kemoterapi menyebabkan penglihatan kabur adalah salah.Hal ini tidak dikung teori dari Reksodiputro (2014) bahwa efek samping kemoterapi yang muncul segera adalah mual, muntah, dan penglihatan kabur.Selain itu terdapat responden yang beranggapan bahwa diare merupakan salah satu efek samping kemoterapi adalah salah. Hal ini tidak didukung teori dari Sudoyo,dkk (2014) yang menyatakan bahwa obat golongan antimetabolit (obat kemoterapi) sering menimbulkan diare. Selain itu untuk analisis jawaban yang paling banyak benar diperoleh bahwa efek samping kemoterapi yang ditimbulkan yaitu mual, muntah dan rambut rontok. Hal ini didukung dari teori Sudoyo,dkk (2014) bahwa efek samping kemoterapi yaitu mual, muntah, rambut rontok, dan diare. Selain itu pendapat serupa juga diperoleh dari Lestari (2013) yaitu efek samping yang ditimbulkan dari pasien leukimia salah satunya adalah kerontokan rambut.Menurut penjelasan di atas bahwa kemungkinan responden belum mengetahui efek yang ditimbulkankarena setiap anak memiliki respon yang berbeda-beda akibat kemoterapi, tergantung jenis kanker yang diderita dan obat yang digunakan.

Tingkat pengetahuan keluarga tentang efek samping kemoterapi jangka panjang diperoleh hasil dalam kategori baik.Aspek pengetahuan tentang efek samping kemoterapi jangka panjang karena keluarga atau responden menganggap bahwa salah satu akibat kemoterapi dapat menyebabkan osteoporosis itu salah.Selain itu keluarga juga beranggapan bahwa kemoterapi tidak menyebabkan sesak napas.Menurut Saleh (2010) bahwa hal-hal yang mempengaruhi efek samping kemoterapi yaitu jenis obat, dosis, jadwal pemberian obat dan faktor predisposisi.Sedangkan menurut Reksodiputro (2014) menyatakan bahwa efek lambat yang timbul akibat kemoterapi adalah osteoporosis, depresi sumsum tulang, dan mukositis. Hal ini juga didukung penelitian oleh Nurhidayah, dkk (2013) bahwa anak yang menjalani kemoterapi akan menimbulkan mukositis. Penjelasan di atas disimpulkan bahwa kemungkinan anak yang menjalani kemoterapi belum sampai pada efek jangka panjang.Sehingga responden (keluarga) belum mengetahui jika efek jangka panjang kemoterapi bisa menimbulkan gejala seperti itu.

Tingkat pengetahuan keluarga tentang penatalaksanaan efek samping kemoterapi jangka pendek diperoleh hasil dalam cukup.Hal ini disebabkan karena responden beranggapan bahwa jika anak diare diberikan makanan yang tinggi serat. Hal ini tidak didukung dari teori Sudoyo,dkk (2014) bahwa pasien dengan diare dianjurkan untuk makan rendah serat, tinggi protein dan cairan yang banyak.

Tingkat pengetahuan keluarga tentang penatalaksanaan efek samping kemoterapi jangka panjang diperoleh hasil dalam kategori baik.Pasien dengan kemoterapi salah satu efek 
yang ditimbulkan adalah terjadinya penurunan kadar hemoglobin atau terjadi anemia. Anemia dapat menyebabkan berbagai gejala seperti lesu,lemah dan sesak napas (Susanto, 2010). Menurut penelitian Yusnaini,dkk (2014) menyatakan bahwa konsumsi jambu biji mampu meningkatkan jumlah serapan zat besi.

Berdasarkan penjelasan di atas bahwa, sebagian responden memiliki pengetahuan yang baik mengenai efek samping kemoterapi. Walaupun begitu fasilitas yang ada di yayasan bahwa kamar mandi atau wc digunakan secara bersamaan. Pasien kanker yang menjalani kemoterapi juga orang yang tinggal bersamanya perlu berhati-hati 48 jam pertama setelah kemoterapi. Karena obat kemoterapi punya efek menimbulkan kanker bagi penderitanya, juga orang di sekitarnya yang kontak dengan muntah, urin, feses, orang yang menjalani kemoterapi. Menurut Dr Ronald A Hukom, MhSc, SpPD-KHOM dari RS Kanker Dharmais, bahwa jika ada yang sedang menjalani kemoterapi, entah anak atau suami di rumah harus tetap hati-hati. Kontak dengan urin, muntah, tinja orang yang menjalani kemoterapi memang tidak banyak, namun hati-hati. Karena muntah, urin, tinja atau produk apa pun dari pasien yang menjalani kemoterapi baru bisa bersih dalam dua hari, jadi 48 jam harus dijaga. Walaupun begitu, bukan berarti keluarga penderita kanker harus memisahkan diri, misalnya tidak menggunakan toilet yang sama. Boleh saja pakai toilet yang sama, asal yakin perilaku pasien di toilet benar atau misalnya menyiram bekas urin dengan benar (Fajri, 2013). Sehingga perlu pengawasan pada anak-anak yang telah melakukan kemoterapi.

\section{Kesimpulan}

Pengetahuan keluarga tentang definisi kemoterapi, tujuan kemoterapi, efek samping kemoterapi jangka pendek dan panjang, penatalaksanaan efek saming jangka panjang dalam kategori baik.Hal ini dikarenakan sebagian besar responden pernah mendapatkan informasi mengenai kemoterapi.

\section{Kelemahan Penelitian}

Penelitian ini hanya mendeskrisikan pengetahuan responden dengan satu variabel, sehingga hasil hanaya pada tataran mengetahui.Diharapkan kepada peneliti selanjutnya untuk meneliti dengan duaatau lebih veriabel yang berhubungan dengan pengetahuan tentang kemoterapi.

\section{Daftar Pustaka}

Fajri, Wardah. (2013). Waspada Efek Kemoterapi untuk Keluarga Pasien Kanker.Diunduh pada tanggal 09 Juli 2017 dari http://lifestyle.kompas.com.

Husnantiya, M. (2014).Waspada, Inilah Kanker yang Paling Sering Menyerang Anak. https://health.detik.com/read/2014/03/27/084347/2538045/1301/waspada-inilahkanker-yang-paling-sering-menyerang-anak.Tesis. Jakarta: Universitas Indonesia.

Kementerian Kesehatan RI. (2013). Riset Kesehatan Dasar (RISKESDAS). Jakarta: Badan Litbang Kemenkes RI.

Kementerian Kesehatan RI. (2015). Situasi penyakit kanker.Buletin.Diunduh pada tanggal 11 Desember 2016 dari www.depkes.go.id.

Lestari, S. (2013). Hubungan Antara Lamanya Kemoterapi Dengan Body Image Pasien Leukemia Limfosit Akut Pada Anak Pra Sekolah Di RSUD Dr. Moewardi Di Surakarta. Skripsi. Surakarta: Universitas Muhammadiyah Surakarta.

Musarofah, S. (2009).Hubungan Antara Tingkat Pengetahuan Terhadap Motivasi Menjalani Kemoterapi di Ruang Cendrawasih Rumah Sakit Umum Pusat Dokter Kariasi 
Semarang.Skripsi. Semarang: Universitas Diponegoro Semarang. Nurhidayah, dkk. (2013). Skor Mukositis Pada Anak Dengan Kanker Yang Sedang Menjalani Kemoterapi Di Rsup Dr. Hasan Sadikin Bandung. Jurnal Keperawatan Soedirman, Volume 8, No 1.

Reksodiputro.(2014). Buku Ajar Ilmu Penyakit Dalam Jilid III edisi VI. Jakarta: Interna Publishing.

Saleh, A.Z. (2010). Buku Acuan Nasional Onkologi Ginekologi Edisi pertama cetakan kedua. Jakarta: Yayasan Bina Pustaka Saewono Prawirohardjo.

Sudoyo, Aru W.,dkk. (2014). Buku Ajar Ilmu Penyakit Dalam Jilid III edisi VI. Jakarta: Interna Publishing.

Susanto, H. (2010). Buku Acuan Nasional Onkologi Ginekologi Edisi pertama

Wawan, A dan Dewi, M. (2010). Pengetahuan Sikap dan Perilaku Manusia. Yogyakarta: Nuha Medika. 